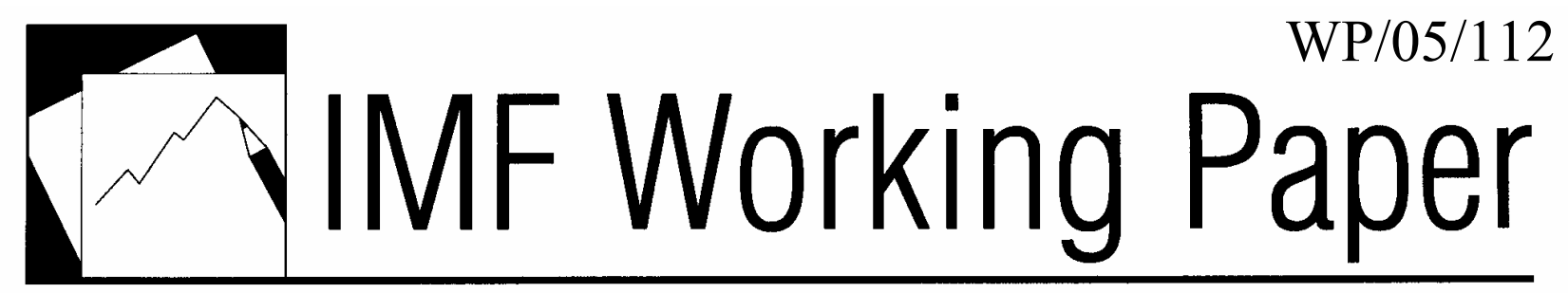

\title{
Tax Revenue and (or?) Trade Liberalization
}

Thomas Baunsgaard and Michael Keen 


\title{
IMF Working Paper
}

Fiscal Affairs Department

\section{Tax Revenue and (or?) Trade Liberalization}

\author{
Prepared by Thomas Baunsgaard and Michael Keen ${ }^{1}$
}

June 2005

\begin{abstract}
This Working Paper should not be reported as representing the views of the IMF. The views expressed in this Working Paper are those of the author(s) and do not necessarily represent those of the IMF or IMF policy. Working Papers describe research in progress by the author(s) and are published to elicit comments and to further debate.

With the public finances of many developing and emerging market countries still heavily dependent on trade tax revenues, further trade liberalization may be hindered unless they are able to develop alternative sources of revenue. While there is now a well-established body of theory and policy advice on how this might be done in principle, this paper uses panel data for 111 countries over 25 years - cleaned for a variety of problems in standard data sources - to ask what has happened in practice: Have countries in fact recovered from other sources the revenues they have lost from past episodes of trade liberalization? High-income countries clearly have. For middle-income countries, recovery has been in the order of 45-60 cents for each dollar of lost trade tax revenue, with signs of close to full recovery when separately identifying episodes in which trade tax revenues fell. Troublingly, however, revenue recovery has been extremely weak in low-income countries (which are those most dependent on trade tax revenues): they have recovered, at best, no more than about 30 cents of each lost dollar. Nor is there much evidence that the presence of a value-added tax has in itself made it easier to cope with the revenue effects of trade liberalization.
\end{abstract}

JEL Classification Numbers: H2, H87, F13

Keywords: Tax reform, trade liberalization

Author(s) E-Mail Address: tbaunsgaard@imf.org and mkeen@imf.org

\footnotetext{
${ }^{1}$ We are grateful to Chiara Bronchi, Laura Clauser, Pravin Krishna, Sajal Lahiri, Eduardo Ley, Janet Stotsky, Teresa Ter-Minassian, Shang-Jin Wei, Yi Wu, and seminar participants for helpful comments. Views and errors are ours alone, and should not be attributed to the International Monetary Fund.
} 


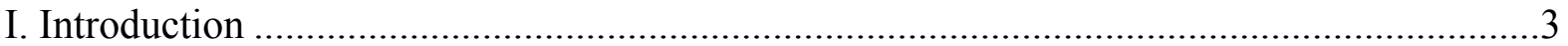

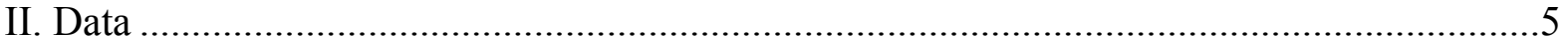

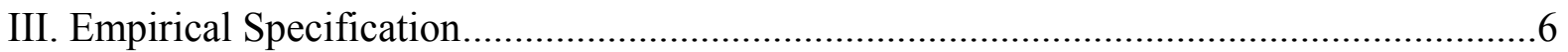

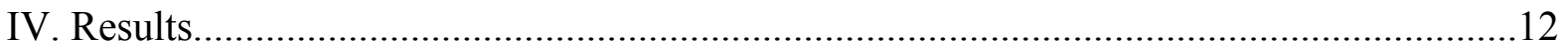

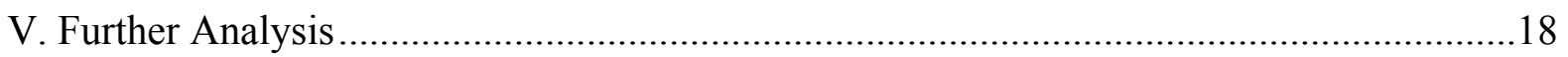

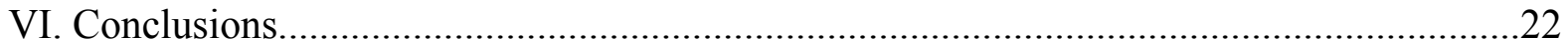

Tables

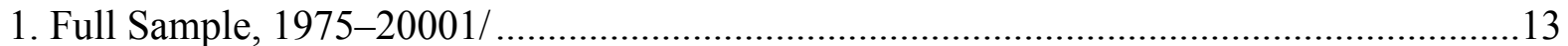

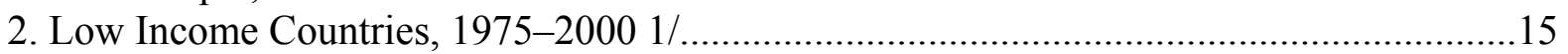

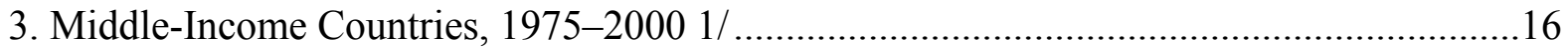

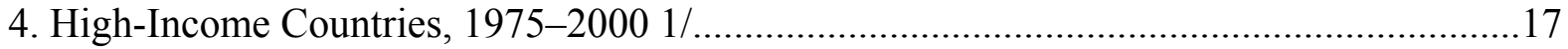

5. Asymmetric Effects, Low- and Middle-Income Countries, 1975-2000 1/ ......................19

6. Further Lags and Non-Linearities, Low- and Middle-Income Countries, 1975-2000 1/....21

Figures

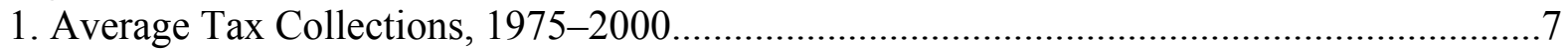

2. Total Tax Revenue and Trade Tax Revenue, 5-Year Averages, 1975-2000 ....................8

Appendix

Data...

Appendix Tables

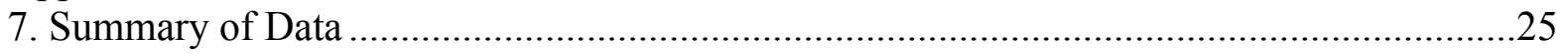

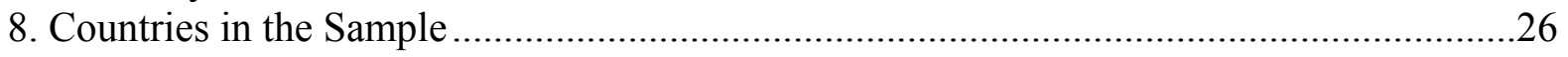

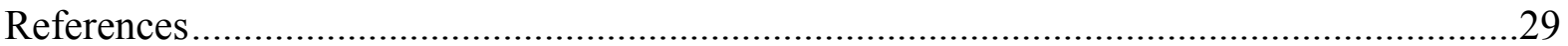




\section{INTRODUCTION}

Despite significant trade liberalization in recent years, many developing and emerging market economies continue to rely heavily on trade taxes as a source of government revenue: in Sub-Saharan Africa, for instance, trade taxes still account for an average of about one-quarter of all government revenues, and in the developing countries of Asia and the Pacific they account for around 15 percent. ${ }^{2}$ A significant concern for many countries as they contemplate further liberalization - whether in the context of proliferating regional agreements, bilateral agreements with the European Union or other developed countries, or in relation to prospective multilateral tariff reduction under the Doha round-is thus the potential impact on tax revenues. These concerns are emerging ever more clearly as a potentially significant obstacle to further trade liberalization.

In the early stages of liberalization, the revenue consequences of reform may be relatively minor. Indeed the first steps of trade policy reform - often involving the reduction of prohibitively high tariffs, tariffication of quotas, elimination of exemptions, and raising of low tariff rates in moving towards a more uniform tariff - may plausibly lead to an increase in trade tax revenues (as discussed and documented by Ebrill and others (1999)). There must come a point, however, at which further movement towards freer trade reduces trade tax revenues. The question then is whether such revenue losses can be recouped from the domestic tax system while maintaining the gains from the trade reform itself. In theory, it is easy to do so, most obviously by strengthening domestic indirect taxes, and there is now a fairly extensive theoretical literature on how to do this. Keen and Ligthart (2001), for example, show that for a small economy a strategy of increasing domestic consumption taxes (slightly less than) one-for-one with tariff cuts has the attractive properties of leaving consumers better off (because the consumer price falls), preserving the production efficiency gain from the tariff reform, and increasing the government's revenue (since consumption is a wider tax base than imports). ${ }^{3}$

What is easy in principle, however, is not always easy in practice. In particular, the well-known relative administrative ease of collecting customs duties may mean that replacement from other sources requires significant reform of wider tax practices. Much of the revenue from a value-added tax (VAT), for instance, is collected at the border (often half or more, in many developing countries) — but implementation of the inland part rests on methods of self-assessment quite different from those commonly used to collect customs duties.

\footnotetext{
${ }^{2}$ Keen and Simone (2004).

${ }^{3}$ There are important caveats to this basic argument, some of which are pursued in Keen and Ligthart (2001, 2003). Hatzipanayotou, Michael, and Miller (1994) and Michael, Hatzipanayotou, and Miller (1993) consider infinitesimal shifts from trade to domestic commodity taxation.
} 
The purpose of this paper is thus to address the empirical question of whether, in practice, countries have indeed been able to make good from domestic sources any loss of revenue from trade taxes that they have experienced. Put (over-)simply, we ask: for each $\$ 1$ of trade tax revenue that they lose, how many dollars have they, in fact, actually recovered from other sources?

Surprisingly, this question seems to have received virtually no attention. Both Ebrill and others (1999) and Khattry and Rao (2002) focus instead on the question of how trade tax revenues are affected by trade liberalization, and on identifying (arguably something of a chimera) a revenue-maximizing tariff rate, beyond which trade tax revenues fall with further tariff cuts. Abgeyegbe, Stotsky, and WoldeMariam (2004) examine how trade liberalization has affected tax revenues (both in total and in the major subcategories) for a panel of countries in Sub-Saharan Africa. The concern in this paper, however, is quite different. It is not with the impact of trade liberalization - measured, say as a reduction in average collected tariff rates - on trade tax revenues, but with the links between trade tax revenues and total tax revenues: measures of trade liberalization that do not affect trade tax revenues simply do not set off the scope for adjustment in other tax revenues that is the starting point of our concern. ${ }^{4}$ Khattry and Rao (2002) do consider the extent to which trade tax revenues have been replaced from other sources, but on this issue - the central concern here - their analysis is only by tabulation. This leads them to somewhat pessimistic conclusions as to the extent to which trade tax revenues have indeed been recovered, especially in low-income countries - but these conclusions, being based on simple correlations, might simply reflect a failure to condition on changes in other variables tending to be associated with lower tax revenues from other sources. It may be that a country has maintained total revenues unchanged following a loss of trade tax revenues, for instance, but feels a lasting effect of the trade reform in those revenues being lower than they otherwise would be given the country's level of real income and other characteristics.

There thus appears to have been no formal econometric assessment of the extent to which countries have in fact succeeded in offsetting reductions in trade tax revenues by increasing revenues from other sources. By examining experience in a large panel of countries, this paper seeks to make such an assessment.

One of the reasons that empirical work in this area has remained so limited appears to be the relative paucity of reliable data on trade tax revenues in developing countries. To overcome this obstacle, we have assembled and use here what we believe to be a reasonably reliable and broad data set comprising 125 countries, and covering the period 1975-2000. ${ }^{5}$ The

\footnotetext{
${ }^{4}$ Thus when we speak somewhat loosely below of the trade tax revenues lost from trade liberalization this is not to imply that trade liberalization always means such revenue losses, but rather that it is only when it does lead to such revenue losses (or conceivably gains) that the issue with which we are concerned arises.

${ }^{5}$ Khattry and Rao (2002) use raw data from the IMF's Government Finance Statistics, covering a slightly longer period (1970-98) and fewer countries (80).
} 
essence of the empirical strategy is then to examine the relationship between total tax revenues and revenue from trade taxes alone (conditioning on other variables likely to be associated with revenue performance), with the two ultimately being independent of one another if and only countries are able, and choose, to replace lost trade tax revenues from other sources.

The plan of the paper is as follows. Section II describes the new dataset used here in more detail, and uses it to take a first look at experience in dealing with the fiscal consequences of reduced trade tax revenues. The conceptual framework for the estimation is developed in Section III. The basic (and troubling) empirical results are in Section IV, with the experiences of low- and middle-income countries explored further in Section V. Section VI concludes.

\section{DATA}

Except for member countries of the Organization for Economic Cooperation and Development (OECD), reliable data on tax revenues in general - and trade tax revenues in particular - are not as readily available as one might expect. The Government Finance Statistics $(G F S)$ produced by the IMF is the most complete source, but suffers from a number of difficulties: the series has many gaps, including missing variables or simply no entries for a particular country, and - a potential source of bias for the empirical strategy we pursuetypically relates only to central government revenues. ${ }^{6}$ Moreover-and of particular importance in the present context - what is recorded as trade tax revenue in many cases, especially in Africa, appears to include VAT and other sales tax collected at the border: thus trade tax reforms that reduce tariff revenue but are offset by an increase in sales tax revenue would go unnoticed. To address these problems, we have taken the GFS data as starting point, but also made use of revenue information provided in the context of the IMF's periodic consultations with member countries. These 'Article IV' data are generally regarded as more reliable, and have been used whenever they conflict with the GFS (not an infrequent occurrence). In doing this we have also made a particular effort to ensure that 'trade tax' revenue does not include revenue from other taxes collected at the border, and to use data for general rather than simply central government. In this way we arrive at an unbalanced panel

\footnotetext{
${ }^{6}$ The difficulty arises from the possibility that reductions in trade tax revenue (almost always allocated to the central government) might be offset by increased revenues at lower levels of government (not recorded in our data for total revenues) - in which case recovery from losses of trade tax revenues would go unremarked. It seems unlikely that this is a serious problem for the approach here, however, since the most obvious instruments for the replacement of trade tax revenues - most notably general sales taxation - are commonly also allocated primarily to central government. The underlying policy issue is, nevertheless, an important one in a number of countries. Rajaraman (2004) stresses, for instance, the obstacle to trade liberalization in India created by the allocation of trade taxes to the central government, but of broad-based sales taxation to the states. Replacing trade tax revenues while leaving spending responsibilities unchanged would thus require an adjustment of vertical transfers.
} 
of 125 countries for the period 1975-2000. Details of this dataset, and other variables used below, are set out in the data appendix.

The basic empirical strategy in our analysis is to examine the relationship between countries' total tax revenue from all sources (including trade taxes) and their revenue from trade taxes alone (both relative to GDP). To the extent that countries are able (and choose) to recoup any revenue lost from trade liberalization, the two should be unrelated - at least over a long enough period of time to allow for possible lags in this recovery. Figures 1 and 2 report basic features of the sample bearing on this.

Figure 1 reports the five-year averages of total and trade tax revenue (relative to GDP) for the sub-groups of the sample comprising 41 low-, 56 middle-, and 28 high-income countries (these being defined by the World Bank classification). ${ }^{7}$ Experience clearly varies widely across the income groups. For the high-income countries, shown in the last panel, the slight reduction in trade tax revenues (which start the sample period at a very low level) coincides with a sustained increase in total tax revenues. For low-income countries, in contrast, a steady reduction in trade tax revenues over the last twenty years has been accompanied by a trend reduction in total revenues - with a clear suggestion that in fact lost trade tax revenues have not been fully recovered from other sources. In the middle-income group, total and trade tax revenues seem to have moved, modestly, in opposite directions: over the last twenty years, total revenues have, on average, increased despite a slight reduction in trade tax revenues.

The data points underlying these averages are presented as scatters of total tax revenue (tr) against trade tax revenue (tt) in Figure 2, each dot representing a five-year average for some country. The simple regression lines tend to confirm the impressions from Figure 1, but also show considerable heterogeneity, pointing to the need to control for other factors affecting the relationship between total and trade tax revenues. It is to this that we now turn.

\section{EMPIRICAL SPECIFICATION}

Some simple analytics are useful for further understanding the issues and guiding the empirics. Consider then a country which raises revenue from two sources: trade taxes, in amount $R^{T}$, and domestic taxes, $R^{D}$. Its welfare is of the form

$$
W(R, X)-\left(\frac{1}{2}\right) \delta^{T}(X)\left(R^{T}\right)^{2}-\left(\frac{1}{2}\right) \delta^{D}(X)\left(R^{D}\right)^{2}
$$

\footnotetext{
${ }^{7}$ Classified by their income position at the end of the sample period. Missing observations mean that not all countries are used in all the regressions below.
} 
Figure 1. Average Tax Collections, 1975-2000

(ii) Low-income countries

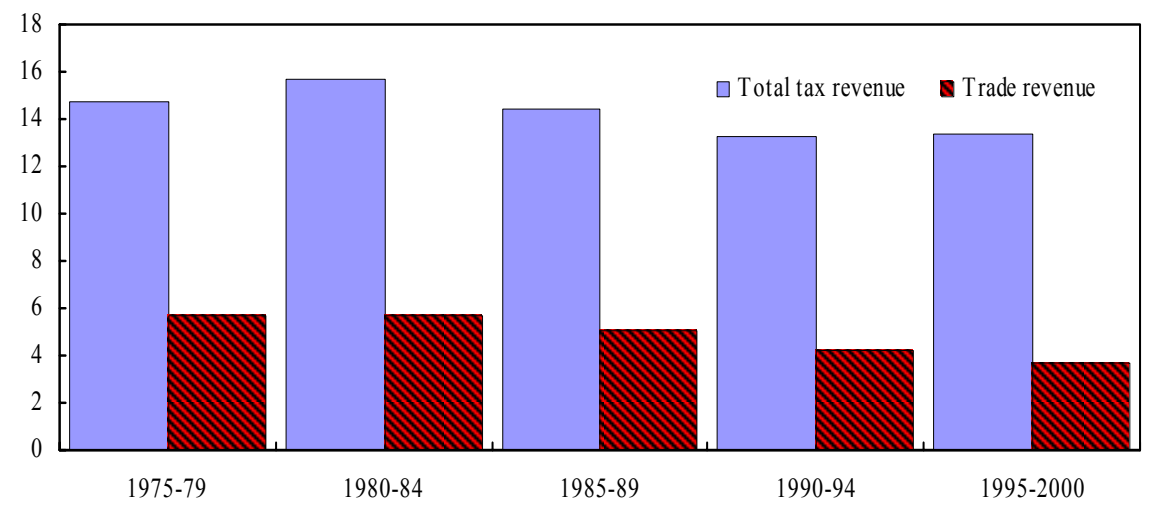

(iii) Middle-income countries

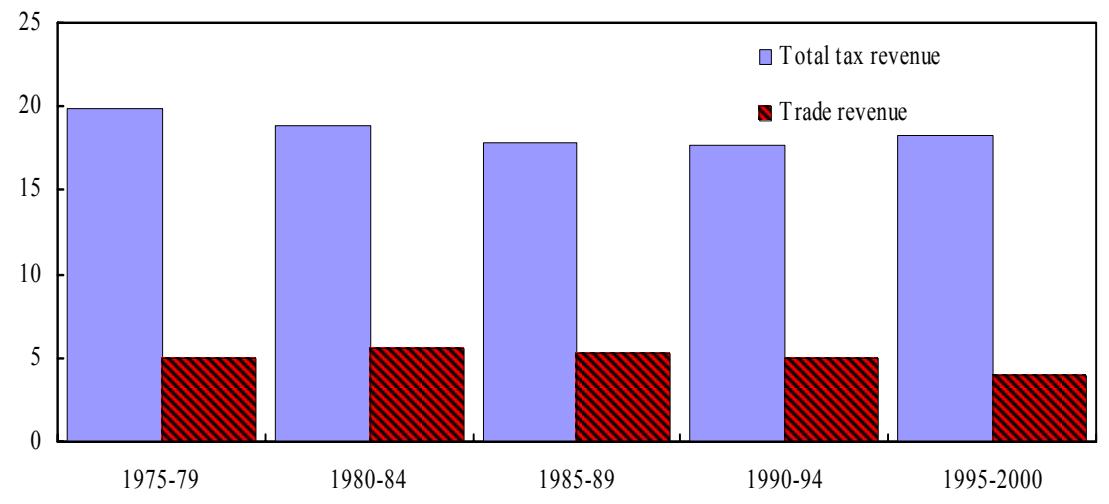

(iv) High-income countries

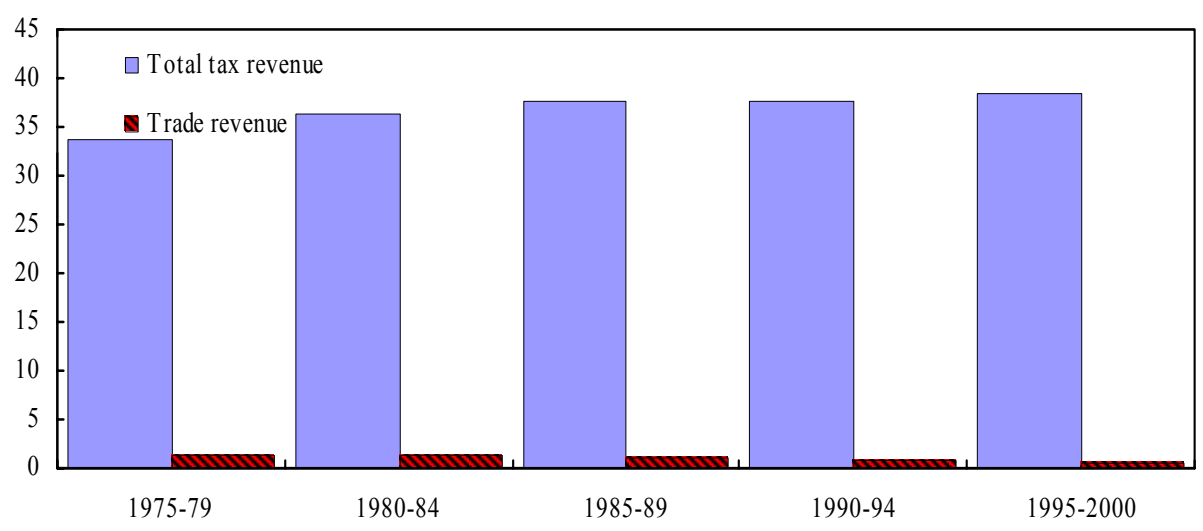


Figure 2. Total Tax Revenue and Trade Tax Revenue, 5-Year Averages, 1975-2000
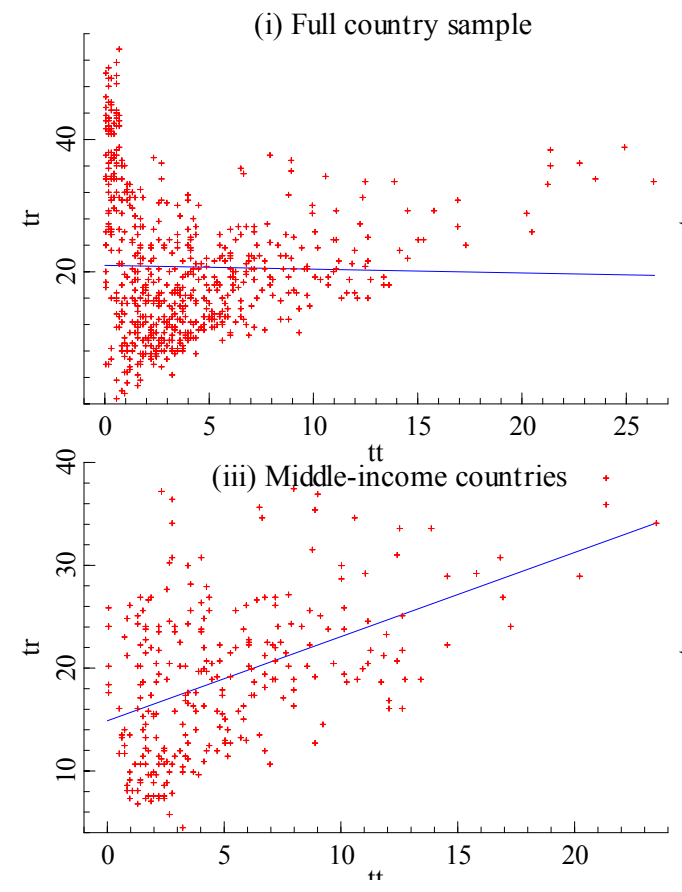

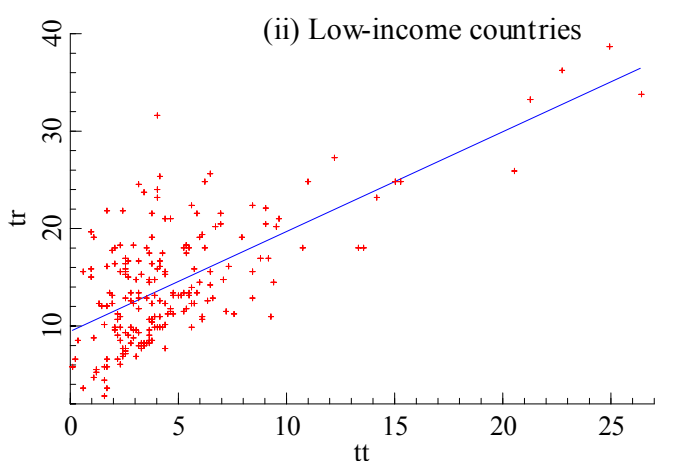

(iv) High-income countries

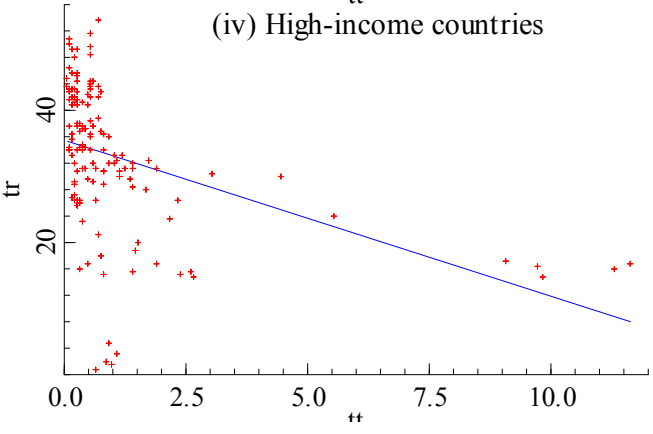

where the function $W(\cdot)$, indicates the welfare derived from public expenditure $R \equiv R^{D}+R^{T}$ and (perhaps in reduced form rather than directly) from a vector $X$ of country-specific conditioning variables, while the terms $\delta^{i}(X)\left(R^{i}\right)^{2}$ reflect the efficiency, administration, and compliance costs associated with the two forms of taxation; thus marginal costs are assumed to increase with the amount raised by each set of tax instruments, and may also depend on the conditioning variables in $X$. If entirely unconstrained in its choice of domestic and trade-related tax instruments, the country would set the underlying tax instruments so that revenues from the two sources satisfy the necessary conditions:

$$
W_{R}(R, X)-\delta^{i}(X) R^{i}=0, \quad i=T, D,
$$

where the subscript indicates a partial derivative, and the second-order condition is satisfied so long as $W(\cdot)$ is concave in $R$. Combining the two conditions gives the simple rule:

$$
\frac{R^{T}}{R}=\frac{\delta^{N}(X)}{\delta^{T}(X)+\delta^{N}(X)}
$$

so that the proportion of total revenue raised from each source reflects its relative costliness. 
A simple way to conceptualize trade liberalization in this context is as an exogenous change in underlying trade tax instruments - dictated perhaps by participation in regional or multilateral negotiations - and hence in the associated revenue. This can be captured by taking $R^{T}$ as parametric but allowing $R^{D}$ to be freely chosen, conditional on that given level of trade tax revenues. From the necessary condition (2) for the choice of domestic revenues, one then finds that

$$
\frac{d R^{D}}{d R^{T}}=\frac{W_{R R}(R, X)}{W_{R R}(R, X)-\delta^{D}(X)}
$$

and hence that reoptimization of domestic revenues in the face of an exogenous change in trade tax revenues — perhaps as a consequence of trade liberalization - implies a final change in total revenues of ${ }^{8}$

$$
\frac{d R}{d R^{T}}=-\left(\frac{\delta^{D}(X)}{\delta^{D}(X)-W_{R R}(R, X)}\right) \in[-1,0] .
$$

The extent to which a country optimally replaces lost trade tax revenues from other sources thus depends, in this highly stylized framework, on two considerations. The first is the costliness of raising revenue from those alternative sources: what matters, note, is not the ease of collecting customs revenue, but the difficulty of collecting anything else. But collection costs (broadly interpreted to include also deadweight losses) are not all that matter. The second consideration is the rapidity with which the marginal value of public expenditure increases as the level of expenditure falls: intuitively, the impact effect of the loss of trade tax revenue is a reduction in public expenditure - and the greater the increase in the marginal value of public expenditure to which this leads, the greater is the tendency to recover revenue from other sources.

Overall, it is also worth stressing, total revenue unambiguously falls. ${ }^{9}$ Intuitively, by constraining the way in which revenue can be raised trade liberalization increases the minimized cost of raising any amount of revenue, and hence results in less being raised. Including a lagged dependent variable to allow for plausible dynamics in policy adjustment (there being significant serial correlation in its absence), these considerations lead to an estimating equation of the form

$$
R_{i t}^{D}=\alpha_{i}+\beta_{0} R_{i, t-1}^{D}+\beta_{1} R_{i t}^{T}+\beta_{2} X_{i t}^{T}+\beta_{3} X_{i t} R_{i t}^{T}+\mu_{t}+\varepsilon_{i t}
$$

\footnotetext{
${ }^{8}$ Note that the first-order condition for $R^{T}$ is not used in deriving (4), which thus applies even when the initial level of trade taxes is not chosen optimally.

${ }^{9}$ Except in the extreme case in which $\delta^{D}=0$; but then trade taxes need not optimally be used at all.
} 
where non-tax and trade tax revenues are now expressed relative to GDP, while $i$ and $t$ are respectively country- and time-indicators (so that $\alpha_{i}$ and $\mu_{t}$ are country- and time-specific effects).

Candidates for inclusion in $X$ are variables that may affect either the valuation of public expenditure or the costliness of raising revenue other than by trade taxes. Drawing on the extensive empirical literature that models the share of total tax revenues in GDP (see, as central examples, Rodrik (1998) and Tanzi (1987)), we take these to include: GDP per capita, (potentially affecting the demand for public expenditure, and also perhaps proxying administrative capacity); openness, measured as the share of imports and exports in GDP (which has robustly been found to be positively associated with the size of government); inflation (an important phenomenon in much of our sample period, with potentially powerful revenue effects through both unindexed tax systems and the generation of seigniorage); aid ${ }^{10}$ per capita (which has been variously found to be positively and negatively associated with the overall level of tax revenue), ${ }^{11}$ and; the share of agriculture in GDP (reflecting the extent of an especially hard-to-tax sector). Also included in $X$ is a dummy variable $V_{i t}$ taking the value unity if country $i$ has a VAT in place in year $t$, and zero otherwise. The question of interest here, given the standard prescription to replace trade tax revenues lost from tariff reform by excises and a broad-based sales tax (the archetype of which is the VAT), is whether those countries which have a VAT do in fact appear to recover more lost trade tax revenues than do those without. For this, we include on the right of (6) not only the VAT dummy itself but also its interaction with trade tax revenues. Drawing on previous work on the revenue impact of the $\mathrm{VAT},{ }^{12}$ interactions of $V$ with openness and GDP per capita are also included. No other interactions between $X$ and trade tax revenues are included; experimentation suggests that they are unimportant in practice, and their absence simplifies interpretation. ${ }^{13}$

Interest centers on the extent to which reductions in trade tax revenues are associated with increases in revenue from domestic taxes. Measuring recovery as a positive number, this is conveniently captured by $-\beta_{1}$ for the short term, and, for the long run, by

$$
\theta \equiv \frac{-\beta_{1}}{\left(1-\beta_{0}\right)} ; \quad \theta_{V} \equiv \frac{-\left(\beta_{1}+\beta_{V}\right)}{\left(1-\beta_{0}\right)}
$$

\footnotetext{
${ }^{10}$ Grants plus concessional loans.

${ }^{11}$ See for instance the review of the evidence in Gupta and others (2004).

${ }^{12}$ See Ebrill and others (2001), who examine the links between VAT and total tax revenue in a cross-section of countries, and Keen and Lockwood (2005) who do so for a panel.

${ }^{13}$ Data definitions, sources, and summary features, recall, are in the Appendix.
} 
for countries with and without a VAT respectively, where $\beta_{V}$ denotes the coefficient on the interaction between trade tax revenue and the VAT dummy (which is of interest in its own right: $\beta_{V}<0$ means that countries with a VAT tend to recoup more lost trade tax revenue than do those without). Full recovery of lost trade tax revenues from domestic sources corresponds to $\theta$ (or, when a VAT is present, $\theta_{V}$ ) $=1$. Conversely, $\theta=0$ implies that any loss of trade tax revenue ultimately implies a loss of total tax revenues of exactly the same amount.

Two key issues arise in interpreting estimates of (6). First, the view of the world motivating the present exercise and the expectation of a negative coefficient $\beta_{1}$ on trade tax revenueswhich is explicit in (4), though not formally required for (6) - is one in which trade tax instruments, and hence the associated revenues, are constrained away from those that countries would otherwise wish to set. The notion is of trade tax policy being set by imperatives beyond the narrowly fiscal. While this seems a reasonable approximation to the experience of many episodes of trade liberalization, it is not the only possibility. And for countries that are unconstrained in their tax and trade policy setting one might plausibly expect a positive relation between trade and domestic tax revenues: a positive shock to the marginal utility of public expenditure $W_{R}$ in (4), for instance, then optimally leads to an increase in both $R^{N}$ and $R^{T}$.

While the data can be left to speak for themselves on the sign of $\beta_{1}$, this observation does have implications for the estimation strategy. It points to the potential endogeneity of trade tax revenues, which indeed can arise for many other reasons too: improvements in customs administration, for example, might increase receipts from both trade taxes and (through its more effective collection at the border) the VAT. To deal with this, results will be reported with trade taxes instrumented by its own lag; and in the GMM estimation (addressed also to the potential bias from inclusion of the lagged dependent variable), trade tax revenue will be treated as predetermined rather than exogenous. This observation also leads us to focus more precisely on the revenue recovery issue by differentiating between episodes in which trade tax revenues increased and episodes in which they decreased, since it is the latter that are most likely to be those in which the revenue recovery issue arises.

Second, it should be stressed that in assessing the revenue impact of trade reform we take no account of potential indirect effects through the $X$ regressors. For instance, trade liberalization may not only reduce trade tax revenues but also lead to an increase in GDP ${ }^{14}$ indeed that may be one reason for undertaking the liberalization-with that increase in income in turn being associated with a higher level of revenue from taxes other than those on trade. Similarly, by expanding the volume of imports and exports trade liberalization may also increase openness, which as will be seen is strongly associated in our sample with

\footnotetext{
${ }^{14}$ The links between trade liberalization, openness and growth remain controversial, of course: see for instance Wacziarg and Welch (2003).
} 
revenue other than from trade taxes. In such ways, trade liberalization may to some degree pay for itself. Modeling these indirect revenue effects would require a structural analysis of the links between these variables and the instruments of trade reform. We do not address these links here, however, but focus on what seems to be the wisest way to pose the policy problem: since growth and other such indirect sources of revenue gain are inherently uncertain, countries considering forgoing trade tax revenue as part of a process of trade liberalization would be well-advised to ask whether they can recover those revenues from other sources even without relying on growth or other such effects of the reform. That is the question to which the empirics are addressed.

\section{RESUlTS}

This section reports the results of estimating equation (6), by a variety of methods, ${ }^{15}$ both for the full sample and successive sub-samples defined by income level.

\section{Full sample}

Table 1 deals with the full sample. The first column reports, by way of a simple benchmark, a fixed effects specification. The pattern of coefficients is broadly as expected. Openness is significantly positively related to domestic tax revenue, and aid per capita negatively so. The somewhat complex pattern of effects associated with the VAT is broadly as in Ebrill and others (2001)) and Keen and Lockwood (2005): the dummy indicates a significantly negative impact on domestic tax revenues, but interaction terms indicate a positive effect that increases with the level of national income and a negative effect (albeit in this case insignificant) that increases with openness. With an exception to which we return, other coefficients (such as that on income per capita) are plausible in sign, though insignificant. Of particular interest here is the significantly negative coefficient on trade tax revenue, with the corresponding estimate of $\theta$ implying that the degree of revenue recovery is significantly different from zero, and in the order of 24 cents for each dollar of lost trade tax revenue (with an average delay of around 2.5 years). Contrary to expectations, the coefficient on the interaction term between the VAT dummy and trade tax revenues is positive, and significantly so (although only just, at 10 percent), indicating that countries with a VAT actually recover less revenue than do those without. Indeed $\theta_{\mathrm{v}}$ is insignificant, indicating essentially no recovery for such countries.

Random effects estimates, reported in the second column, are inherently less plausible: openness emerges as insignificant, the share of agriculture as positively related to non-tax revenue, and trade tax revenues are insignificant. And indeed the Hausman test firmly favors the fixed effects model, rejecting independence of the country-specific effects and the regressors.

\footnotetext{
${ }^{15}$ All regressions include a full set of time dummies, results for which are omitted.
} 
Table 1. Full Sample, 1975-2000"1/

\begin{tabular}{|c|c|c|c|c|}
\hline & Deper & Variable: Nol & Trade Tax Re & \\
\hline & (1) & (2) & (3) & (4) \\
\hline & FE & $\mathrm{RE}$ & IV & GMM 2/ \\
\hline Lagged domestic revenue & $0.711 * *$ & $0.975^{* *}$ & $0.713 * *$ & $0.472 * *$ \\
\hline & $(0.160)$ & $(0.006)$ & $(0.160)$ & $(0.057)$ \\
\hline Trade tax to GDP & $-0.070 * *$ & 0.195 & -0.049 & $-0.267 * *$ \\
\hline & $(0.028)$ & $(0.145)$ & $(0.038)$ & $(0.109)$ \\
\hline Trade tax $\times$ VAT & $0.105^{*}$ & 0.013 & -0.057 & 0.352 \\
\hline & $(0.028)$ & $(0.046)$ & $(0.101)$ & $(0.265)$ \\
\hline VAT & $-1.656^{* *}$ & -0.077 & -0.454 & 0.000 \\
\hline & $(0.063)$ & $(0.644)$ & $(1.002)$ & $(2.316)$ \\
\hline Openness & $0.009 * *$ & 0.001 & $0.009 * *$ & $0.019 * *$ \\
\hline & $(0.003)$ & $(0.002)$ & $(0.003)$ & $(0.007)$ \\
\hline Openness $\times$ VAT & -0.004 & -0.001 & -0.002 & 0.000 \\
\hline & $(0.003)$ & $(0.002)$ & $(0.003)$ & $(0.007)$ \\
\hline Log per capita GDP & 0.041 & $0.346^{* *}$ & 0.077 & 1.24 \\
\hline & $(0.324)$ & $(0.076)$ & $(0.325)$ & $(1.176)$ \\
\hline Log per capita GDP $\times$ VAT & $0.207 * *$ & 0.019 & 0.096 & 0.014 \\
\hline & $(0.098)$ & $(0.077)$ & $(0.111)$ & $(0.291)$ \\
\hline Log inflation & 0.029 & $0.095 * *$ & 0.032 & 0.057 \\
\hline & $(0.052)$ & $(0.041)$ & $(0.052)$ & $(0.103)$ \\
\hline Aid per capita & $-0.004 * *$ & -0.001 & $-0.004 * *$ & $-0.004 * *$ \\
\hline & $(0.001)$ & $(0.001)$ & $(0.001)$ & $(0.002)$ \\
\hline Share of agriculture & -0.011 & $0.018 * *$ & $-0.009 * *$ & -0.018 \\
\hline & $(0.014)$ & $(0.006)$ & $(0.014)$ & $(0.036)$ \\
\hline Implied $\theta 3 /$ & $0.243 * *$ & -0.769 & 0.172 & $0.505^{* *}$ \\
\hline Implied $\theta_{\mathrm{V}} 3 /$ & -.119 & -1.262 & 0.372 & -0.162 \\
\hline & $(0.221)$ & $(1.801)$ & $(0.350)$ & $(0.531)$ \\
\hline $\mathrm{R}^{2}$ & 0.973 & 0.976 & 0.973 & \\
\hline Hausman 4/ & & $336.4^{* *}(34)$ & & \\
\hline $\mathrm{m} 15 /$ & & & & $-5.13 * *$ \\
\hline $\mathrm{m} 25 /$ & & & & 0.04 \\
\hline Sargan 6/ & & & & 1.00 \\
\hline Number of observations & 2083 & 2083 & 2083 & 1913 \\
\hline
\end{tabular}

Source: Authors' calculations.

1/ Dependent variable is ratio of domestic tax revenue to GDP. Full set of year dummies in all regressions. Standard errors in parentheses; ** $(*)$ indicates significance at $5(10)$ percent.

2/ One step estimates with robust standard errors, except as in footnote 4.

$3 /$ Standard errors calculated using delta method.

4/ Distributed $\chi^{2}$ with degrees of freedom under null in parentheses.

$5 /$ Distributed N( 0,1$)$ under the null.

6/ p-value from two-step GMM. 
The third column addresses the potential endogeneity of trade tax revenues, instrumenting it by its own lag. The pattern of coefficients is much as in the fixed effects case-except that now countries with a VAT recover more, rather than less, than do those without - but in many cases smaller in magnitude and now insignificant. The degree of revenue recovery, both for those with a VAT and those without, is now insignificantly different from zero.

Finally, to address both the endogeneity of trade tax revenues and the bias from the presence of the lagged dependent variable, the fourth column estimates the same specification (in first differences) by one-step GMM. ${ }^{16}$ These perform well in terms of the standard specification tests, showing the first-order serial correlation expected from first differencing and the absence of second-order correlation required for consistency, and the Sargan test (from the two-step GMM estimation of the analogous equation ${ }^{17}$ ) does not reject the over-identifying restrictions. The estimates are broadly plausible (though, notably, all terms involving the VAT dummy are now insignificant). The degree of revenue recovery is significant, as in the fixed effects case, and is now both stronger and more rapid: ${ }^{18}$ about 50 cents is recovered for each dollar lost, with the average delay now being under one year.

While the results for the various specifications are clearly mixed, discarding the rejected random effect specification suggests that the degree of revenue recovery across the full sample has been significant, but far from complete: perhaps in the order of 20-50 cents per dollar, with the preferred GMM estimates pointing to the upper part of this range.

\section{Results by income group}

Tables 2-4 report results for the sub-samples of low, middle and high income countries. The sequence of specifications is the same as for the full sample, as, for the most part, are the results of the diagnostic tests (with rejection of the random effects specification ${ }^{19}$ and satisfactory performance of GMM). The discussion therefore focuses on the key question of interest: the degree of revenue recovery.

\footnotetext{
16 The instruments are lags dated $t-1$ to $t-3$ for all regressors other than the lagged dependent variable and (given the potential endogeneity noted above) trade tax revenues, for which lags dated $t-2$ to $t-4$ are used. One- rather than two-step estimates are generally preferred for inference (Arrelano and Bond (1991)).

${ }^{17}$ This is reported because the Sargan statistic from one-step GMM is generally not normally distributed.

${ }^{18}$ The extent of the apparent bias in the fixed effect and instrumental variable estimates of the coefficient on the lagged dependent variable is striking, given that this is not a particularly short panel. That the bias appears to be upwards presumably reflects the presence of additional regressors (without which it would be downwards).

${ }^{19}$ Except for the sub-sample of high-income countries, which in any event prove of little interest, as discussed below.
} 
Table 2. Low Income Countries, 1975-2000 1/

\begin{tabular}{|c|c|c|c|c|}
\hline & \multicolumn{4}{|c|}{ Dependent Variable: Non-Trade Tax Revenue } \\
\hline & (1) & $\begin{array}{l}(2) \\
\text { RF }\end{array}$ & (3) & $\begin{array}{c}(4) \\
M M\end{array}$ \\
\hline Lagged domestic revenue & $\begin{array}{l}0.660^{* *} \\
(0.032)\end{array}$ & $\begin{array}{l}0.886^{* *} \\
(0.197)\end{array}$ & $\begin{array}{l}0.660 * * \\
(0.033)\end{array}$ & $\begin{array}{l}0.582 * * \\
(0.049)\end{array}$ \\
\hline Trade tax to GDP & $\begin{array}{l}-0.027 \\
(0.048)\end{array}$ & $\begin{array}{l}-0.009 \\
(0.026)\end{array}$ & $\begin{array}{c}-0.053 \\
(0.077)\end{array}$ & $\begin{array}{l}-0.125^{* *} \\
(0.058)\end{array}$ \\
\hline Trade tax $\times$ VAT & $\begin{array}{c}0.109 \\
(0.115)\end{array}$ & $\begin{array}{c}-0.018 \\
(0.083)\end{array}$ & $\begin{array}{c}-0.056 \\
(0.201)\end{array}$ & $\begin{array}{c}0.336 \\
(0.217)\end{array}$ \\
\hline VAT & $\begin{array}{l}-0.661 \\
(2.787)\end{array}$ & $\begin{array}{c}0.293 \\
(1.970)\end{array}$ & $\begin{array}{c}0.033 \\
(2.842)\end{array}$ & $\begin{array}{c}1.028 \\
(5.077)\end{array}$ \\
\hline Openness & $\begin{array}{l}0.033^{* *} \\
(0.008)\end{array}$ & $\begin{array}{l}0.010^{* *} \\
(0.005)\end{array}$ & $\begin{array}{l}0.033^{* *} \\
(0.009)\end{array}$ & $\begin{array}{l}0.046^{* *} \\
(0.023)\end{array}$ \\
\hline Openness $\times$ VAT & $\begin{array}{l}-0.027 * * \\
(0.011)\end{array}$ & $\begin{array}{c}0.002 \\
(0.009)\end{array}$ & $\begin{array}{l}-0.023 * * \\
(0.012)\end{array}$ & $\begin{array}{l}-0.044^{*} \\
(0.023)\end{array}$ \\
\hline Log per capita GDP & $\begin{array}{c}0.296 \\
(0.647)\end{array}$ & $\begin{array}{c}0.320 \\
(0.242)\end{array}$ & $\begin{array}{c}0.290 \\
(0.667)\end{array}$ & $\begin{array}{l}2.099 * * \\
(0.763)\end{array}$ \\
\hline Log per capita GDP $\times$ VAT & $\begin{array}{c}0.257 \\
(0.486)\end{array}$ & $\begin{array}{l}-0.042 \\
(0.339)\end{array}$ & $\begin{array}{c}0.200 \\
(0.489)\end{array}$ & $\begin{array}{c}0.059 \\
(0.927)\end{array}$ \\
\hline Log inflation & $\begin{array}{l}-0.058 \\
(0.096)\end{array}$ & $\begin{array}{c}0.062 \\
(0.077)\end{array}$ & $\begin{array}{c}-0.40 \\
(0.098)\end{array}$ & $\begin{array}{l}-0.099 \\
(0.153)\end{array}$ \\
\hline Aid per capita & $\begin{array}{l}-0.001 \\
(0.005)\end{array}$ & $\begin{array}{l}-0.002 \\
(0.004)\end{array}$ & $\begin{array}{l}-0.001 \\
(0.005)\end{array}$ & $\begin{array}{l}-0.004 \\
(0.004)\end{array}$ \\
\hline Share of agriculture & $\begin{array}{l}-0.013 \\
(0.019)\end{array}$ & $\begin{array}{l}-0.005 \\
(0.010)\end{array}$ & $\begin{array}{c}0.009 \\
(0.019)\end{array}$ & $\begin{array}{c}0.007 \\
(0.021)\end{array}$ \\
\hline Implied $\theta 3 /$ & $\begin{array}{c}0.078 \\
(0.140)\end{array}$ & $\begin{array}{c}0.077 \\
(0.227)\end{array}$ & $\begin{array}{c}0.155 \\
(0.222)\end{array}$ & $\begin{array}{l}0.299 * * \\
(0.137)\end{array}$ \\
\hline Implied $\theta_{\mathrm{V}} 3 /$ & $\begin{array}{c}-0.241 \\
(0.327)\end{array}$ & $\begin{array}{c}0.231 \\
(0.688)\end{array}$ & $\begin{array}{c}0.320 \\
(0.551)\end{array}$ & $\begin{array}{l}-0.505 \\
(0.500)\end{array}$ \\
\hline $\begin{array}{l}\mathrm{R}^{2} \\
\text { Hausman 4/ } \\
\mathrm{m} 15 / \\
\mathrm{m} 25 / \\
\text { Sargan 6/ }\end{array}$ & 0.827 & $\begin{array}{l}0.858 \\
99.59 * *(35)\end{array}$ & 0.831 & $\begin{array}{l}-3.24 * * \\
0.20 \\
1.0\end{array}$ \\
\hline Number of countries & 35 & 35 & 35 & 35 \\
\hline Number of observations & 590 & 590 & 590 & 524 \\
\hline
\end{tabular}

Source: Authors' calculations.

1/ Dependent variable is ratio of domestic tax revenue to GDP. Full set of year dummies in all regressions. Standard errors in parentheses; ** $(*)$ indicates significance at 5 (10) percent.

2/ One step estimates with robust standard errors, except as in footnote 4.

3/ Standard errors calculated using delta method.

4/ Distributed $\chi^{2}$ with degrees of freedom under null in parentheses.

5/ Distributed N(0,1) under the null.

6/ p-value from two-step GMM. 
Table 3. Middle-Income Countries, 1975-2000 1/

\begin{tabular}{|c|c|c|c|c|}
\hline \multirow{3}{*}{-} & \multicolumn{4}{|c|}{ Dependent Variable: Non-Trade Tax Revenue } \\
\hline & (1) & $(2)$ & (3) & (4) \\
\hline & FE & $\mathrm{RE}$ & IV & GMM 2/ \\
\hline Lagged domestic revenue & $\begin{array}{l}0.651 * * \\
(0.024)\end{array}$ & $\begin{array}{l}0.939 * * \\
(0.012)\end{array}$ & $\begin{array}{l}0.659 * * \\
(0.025)\end{array}$ & $\begin{array}{l}0.477 * * \\
(0.071)\end{array}$ \\
\hline \multirow[t]{2}{*}{ Trade tax to GDP } & $-0.157 * *$ & 0.013 & -0.081 & $-0.342 * *$ \\
\hline & $(0.040)$ & $(0.022)$ & $(0.055)$ & $(0.133)$ \\
\hline \multirow[t]{2}{*}{ Trade tax $\times$ VAT } & 0.094 & 0.049 & 0.112 & 0.269 \\
\hline & $(0.097)$ & $(0.073)$ & $(0.166)$ & $(0.228)$ \\
\hline \multirow[t]{2}{*}{ VAT } & 0.951 & -0.250 & 1.040 & -5.252 \\
\hline & $(2.750)$ & $(1.818)$ & $(3.096)$ & $(6.819)$ \\
\hline \multirow[t]{2}{*}{ Openness } & 0.005 & 0.004 & 0.004 & $0.016^{* *}$ \\
\hline & $(0.004)$ & $(0.003)$ & $(0.004)$ & $(0.006)$ \\
\hline \multirow[t]{2}{*}{ Openness $\times$ VAT } & $0.013^{*}$ & -0.002 & 0.013 & 0.009 \\
\hline & $(0.008)$ & $(0.004)$ & $(0.008)$ & $(0.016)$ \\
\hline \multirow[t]{2}{*}{ Log per capita GDP } & -0.392 & -0.005 & -0.309 & $-2.26^{*}$ \\
\hline & $(0.520)$ & $(0.175)$ & $(0.534)$ & $(1.374)$ \\
\hline \multirow[t]{2}{*}{ Log per capita GDP $\times$ VAT } & -0.348 & 0.008 & -0.370 & 0.380 \\
\hline & $(0.373)$ & $(0.234)$ & $(0.401)$ & $(0.943)$ \\
\hline \multirow[t]{2}{*}{ Log inflation } & 0.070 & -0.005 & 0.082 & $0.201 *$ \\
\hline & $(0.076)$ & $(0.175)$ & $(0.076)$ & $(0.112)$ \\
\hline \multirow[t]{2}{*}{ Aid per capita } & $-0.004 * *$ & -0.001 & $-0.004 * *$ & -0.002 \\
\hline & $(0.001)$ & $(0.001)$ & $(0.001)$ & $(0.002)$ \\
\hline \multirow[t]{2}{*}{ Share of agriculture } & -0.023 & -0.016 & -0.024 & -0.102 \\
\hline & $(0.024)$ & $(0.013)$ & $(0.024)$ & $(0.090)$ \\
\hline Implied $\theta 3 /$ & $\begin{array}{l}0.450 * * \\
(0.114)\end{array}$ & $\begin{array}{l}-0.214 \\
(0.370)\end{array}$ & $\begin{array}{c}0.238 \\
(0.159)\end{array}$ & $\begin{array}{l}0.654 * * \\
(0.244)\end{array}$ \\
\hline \multirow[t]{2}{*}{ Implied $\theta_{\mathrm{V}} 3 /$} & 0.180 & -1.016 & -0.091 & 0.139 \\
\hline & $(0.279)$ & $(1.153)$ & $(0.471)$ & $(0.422)$ \\
\hline $\mathrm{R}^{2}$ & 0.861 & 0.896 & 0.874 & \\
\hline Hausman 4/ & & $209.29 * *(35)$ & & \\
\hline $\mathrm{m} 15 /$ & & & & $-3.44 * *$ \\
\hline $\mathrm{m} 25 /$ & & & & 0.35 \\
\hline Sargan 6/ & & & & 1.0 \\
\hline Number of countries & 50 & 50 & 50 & 49 \\
\hline Number of observations & 966 & 966 & 966 & 894 \\
\hline
\end{tabular}

Source: Authors' calculations.

1/ Dependent variable is ratio of domestic tax revenue to GDP. Full set of year dummies in all regressions. Standard errors in parentheses; $* *(*)$ indicates significance at $5(10)$ percent.

2/ One step estimates with robust standard errors, except as in footnote 4.

3/ Standard errors calculated using delta method.

4/ Distributed $\chi 2$ with degrees of freedom under null in parentheses.

5/ Distributed N(0,1) under the null.

6/ p-value from two-step GMM. 
Table 4. High-Income Countries, 1975-2000 1/

\begin{tabular}{|c|c|c|c|c|}
\hline & \multicolumn{4}{|c|}{ Dependent Variable: Non-Trade Tax Revenue } \\
\hline & (1) & $(2)$ & (3) & (4) \\
\hline & FE & $\mathrm{RE}$ & IV & GMM 2/ \\
\hline \multirow[t]{2}{*}{ Lagged domestic revenue } & $0.852 * *$ & $0.986 * *$ & $0.848 * *$ & $0.777 * *$ \\
\hline & $(0.025)$ & $(0.009)$ & $(0.167)$ & $(0.028)$ \\
\hline \multirow[t]{2}{*}{ Trade tax to GDP } & $-0.271 *$ & $-0.138 * *$ & $-0.495 * *$ & $-0.341 *$ \\
\hline & $(0.150)$ & $(0.062)$ & $(0.166)$ & $(0.208)$ \\
\hline \multirow[t]{2}{*}{ Trade tax $\times$ VAT } & -0.300 & -0.212 & 0.204 & -0.312 \\
\hline & $(0.258)$ & $(0.186)$ & $(0.407)$ & $(0.291)$ \\
\hline \multirow[t]{2}{*}{ VAT } & 4.860 & 2.626 & 1.785 & 8.258 \\
\hline & $(4.052)$ & $(3.180)$ & $(4.450)$ & $(5.563)$ \\
\hline \multirow[t]{2}{*}{ Openness } & -0.007 & -0.000 & -0.006 & -0.009 \\
\hline & $(0.007)$ & $(0.002)$ & $(0.007)$ & $(0.011)$ \\
\hline \multirow[t]{2}{*}{ Openness $\times$ VAT } & -0.001 & -0.002 & -0.001 & -0.002 \\
\hline & $(0.003)$ & $(0.002)$ & $(0.003)$ & $(0.003)$ \\
\hline \multirow[t]{2}{*}{ Log per capita GDP } & 0.085 & 0.433 & -0.146 & 0.316 \\
\hline & $(0.815)$ & $(0.292)$ & $(0.826)$ & $(1.042)$ \\
\hline \multirow[t]{2}{*}{ Log per capita GDP $\times$ VAT } & -0.474 & -0.249 & -0.208 & -0.819 \\
\hline & $(0.410)$ & $(0.322)$ & $(0.442)$ & $(0.518)$ \\
\hline \multirow[t]{2}{*}{ Log inflation } & 0.092 & $0.171^{*}$ & 0.120 & 0.135 \\
\hline & $(0.106)$ & $(0.090)$ & $(0.107)$ & $(0.117)$ \\
\hline \multirow[t]{2}{*}{ Aid per capita } & 0.041 & 0.032 & 0.042 & $0.045^{* *}$ \\
\hline & $(0.026)$ & $(0.025)$ & $(0.026)$ & $(0.010)$ \\
\hline \multirow[t]{2}{*}{ Share of agriculture } & 0.015 & $0.041 *$ & -0.021 & -0.032 \\
\hline & $(0.056)$ & $(0.023)$ & $(0.063)$ & $(0.077)$ \\
\hline \multirow[t]{2}{*}{ Implied $\theta 3 /$} & $1.833^{*}$ & 9.572 & $3.261 * *$ & $1.529^{*}$ \\
\hline & $(1.021)$ & (6.169) & $(1.152)$ & $(0.913)$ \\
\hline \multirow[t]{2}{*}{ Implied $\theta_{\mathrm{V}} 3 /$} & $3.864 * *$ & 24.262 & 1.916 & $2.928^{* *}$ \\
\hline & $(1.824)$ & $(16.360)$ & $(2.605)$ & $(1.353)$ \\
\hline $\mathrm{R}^{2}$ & 0.985 & 0.988 & 0.984 & \\
\hline Hausman 4/ & & $38.38(35)$ & & \\
\hline $\mathrm{m} 15 /$ & & & & $-3.07 * *$ \\
\hline $\mathrm{m} 25 /$ & & & & 0.94 \\
\hline Sargan 6/ & & & & 1.0 \\
\hline Number of countries & 26 & 26 & 26 & 26 \\
\hline Number of observations & 525 & 525 & 525 & 493 \\
\hline
\end{tabular}

Source: Authors' calculations.

1/ Dependent variable is ratio of domestic tax revenue to GDP. Full set of year dummies in all regressions. Standard errors in parentheses; $* *(*)$ indicates significance at $5(10)$ percent.

2/ One step estimates with robust standard errors, except as in footnote 4.

3/ Standard errors calculated using delta method.

4/ Distributed $\chi 2$ with degrees of freedom under null in parentheses.

$5 /$ Distributed N(0,1) under the null.

6/ p-value from two-step GMM. 
For low-income countries (Table 2), only the (preferred) GMM estimates show any significant revenue recovery at all, and then of only around 30 cents for each dollar of lost trade tax revenue. The presence or absence of a VAT makes no significant difference to the degree of recovery in the short-term; and indeed the long-run recovery of those with a VAT is insignificantly different from zero. Low-income countries, it appears, have, for whatever reason, very largely failed to recover from domestic sources such revenue as they have lost from trade reform.

Middle-income countries (Table 3) have a noticeably stronger record of revenue recovery, although this is still less than complete. Aside from the instrumental variables results, which are again rather feeble, they suggest recovery in the range of 45 to 65 cents per dollar.

The results for high-income countries (Table 4) once again point to a negative relationship between revenues from domestic and trade taxes, and indeed to recovery well in excess of a dollar per dollar. ${ }^{20}$ Within this group, recovery is also higher for those countries with a VAT. But the excess recovery of lost trade tax revenues in this group seems best interpreted as signaling that for them the revenue impact of trade taxes is a very secondary consideration in their design. For the high-income countries, trade taxes are essentially just protective devices, there evidently being no difficulty in replacing the revenues they yield.

\section{FURTher ANALYSIS}

This section explores further the experiences of low- and middle-income countries. (The high-income group is left aside, since the previous results tended to confirm that revenue recovery is not a significant issue for them).

\section{Asymmetries}

As discussed above, the revenue recovery question is more one of offsetting falls in trade tax revenues by increasing domestic taxes than it is of cutting domestic taxes when trade tax revenues for some reason increase. To recognize this asymmetry and focus directly on the case of interest, Table 5 reports GMM estimates ${ }^{21}$ allowing domestic tax revenues to respond differently to increases and reductions in trade tax revenue. ${ }^{22}$ Thus $\theta$ (minus), for instance,

\footnotetext{
${ }^{20}$ The positive impact of aid receipts for this group reflects some outlying observations in the early part of the period. Ad hoc removal of these leaves the results of interest essentially unaffected.

${ }^{21}$ Fixed effects results are not reported since the first-order serial correlation that the GMM estimates show for the differenced equation mean that they would be (strongly) biased.

${ }^{22}$ For the full sample of low- (respectively, middle-) income countries, trade tax revenues decrease in about 53 (60) percent of cases. The dominant trend for both groups, recall from Figure 1, is a decrease in trade tax revenues.
} 
Table 5. Asymmetric Effects, Low- and Middle-Income Countries, 1975-2000 1/

\begin{tabular}{|c|c|c|}
\hline & Low Income & Middle Income \\
\hline$\Delta$ Lagged domestic revenue & $\begin{array}{l}0.520^{* *} \\
(0.058)\end{array}$ & $\begin{array}{l}0.483 * * \\
(0.07)\end{array}$ \\
\hline$\Delta$ Trade tax plus & $\begin{array}{c}0.112 \\
(0.087)\end{array}$ & $\begin{array}{l}-0.195 \\
(0.162)\end{array}$ \\
\hline$\Delta$ Trade tax minus & $\begin{array}{l}-0.133 \\
(0.082)\end{array}$ & $\begin{array}{l}-0.496^{* *} \\
(0.169)\end{array}$ \\
\hline$(\Delta$ Trade tax plus $) \times$ VAT & $\begin{array}{c}0.025 \\
(0.253)\end{array}$ & $\begin{array}{l}1.089 * * \\
(0.450)\end{array}$ \\
\hline$(\Delta$ Trade tax minus $) \times$ VAT & $\begin{array}{c}-0.071 \\
(0.204)\end{array}$ & $\begin{array}{c}-0.095 \\
(0.280)\end{array}$ \\
\hline$\Delta$ Openness & $\begin{array}{l}0.034^{* *} \\
(0.013)\end{array}$ & $\begin{array}{l}0.019 * * \\
(0.006)\end{array}$ \\
\hline$\Delta$ Log per capita GDP & $\begin{array}{l}3.598^{* *} \\
(1.038)\end{array}$ & $\begin{array}{l}-1.484 \\
(1.722)\end{array}$ \\
\hline$\Delta$ Log inflation & $\begin{array}{c}-0.056 \\
(0.144)\end{array}$ & $\begin{array}{c}0.131 \\
(0.111)\end{array}$ \\
\hline$\Delta$ Aid per capita & $\begin{array}{l}-0.004 \\
(0.005)\end{array}$ & $\begin{array}{l}-0.002 \\
(0.002)\end{array}$ \\
\hline$\Delta$ Share of agriculture & $\begin{array}{c}-0.016 \\
(0.023)\end{array}$ & $\begin{array}{l}-0.103 \\
(0.100)\end{array}$ \\
\hline Implied $\theta$ (plus) $3 /$ & $\begin{array}{c}-0.234 \\
(0.166)\end{array}$ & $\begin{array}{c}0.378 \\
(0.310)\end{array}$ \\
\hline Implied $\theta(\text { plus })_{\mathrm{V}} 3 /$ & $\begin{array}{c}-0.286 \\
(0.465)\end{array}$ & $\begin{array}{l}-1.727 \\
(0.823)\end{array}$ \\
\hline Implied $\theta$ (minus) $3 /$ & $\begin{array}{c}0.277 \\
(0.172)\end{array}$ & $\begin{array}{l}0.956 * * \\
(0.327)\end{array}$ \\
\hline Implied $\theta$ (minus $)_{\mathrm{V}} 3 /$ & $\begin{array}{c}0.425 \\
(0.387)\end{array}$ & $\begin{array}{l}1.143^{* *} \\
(0.478)\end{array}$ \\
\hline $\mathrm{m} 13 /$ & $-3.16^{* *}$ & $-3.4 * *$ \\
\hline $\mathrm{m} 23 /$ & 0.11 & 0.55 \\
\hline Sargan 4/ & 1.0 & 1.0 \\
\hline Number of countries & 35 & 49 \\
\hline Number of observations & 524 & 894 \\
\hline
\end{tabular}

Source: Authors' calculations.

1/ Dependent variable is change in ratio of domestic tax revenue to GDP. Estimation by one-step GMM, with full set of year dummies in all regressions. Standard errors in parentheses; ** $\left(^{*}\right)$ indicates significance at $5(10)$ percent.

2/ One step estimates with robust standard errors, except as in footnote 4.

3/ Distributed N(0,1) under the null.

4/ p-value from two-step GMM. 
refers to the degree of recovery associated with a cut in trade tax revenue, and $\theta($ plus $)$ to the increase in domestic tax revenues associated with an increase in trade tax revenues.

The results tend to reinforce the impression of very weak recovery in low-income countries. At 28 cents in the dollar, this is of about the same order as found when no distinction is made between episodes of decreasing and increasing trade tax revenues-but now it is insignificant. There are signs that those with a VAT recover somewhat more completely, closer to 40 percent, but recovery remains insignificant.

For middle-income countries, however, a much more solid tendency to recover lost trade tax revenues emerges than was apparent before. Indeed for them the degree of recovery is essentially 100 percent; and those of them with a VAT recover noticeably more.

\section{Robustness}

Table 6 reports the results of allowing trade tax revenue to appear as a regressor with a lag and (by adding a squared term) non-linearly. Results are reported only for the fixed effects specification (as a basic benchmark) and for one-step GMM (which in principle deals also with the endogeneity to which the IV estimation is addressed).

For low-income countries, all regressors related to trade taxes are now insignificant, suggesting little need to qualify the conclusions above. For middle-income countries, there are strong signs of non-linearity, with the recovery of trade tax revenue becoming harder the lower their initial level. At the average level of trade tax revenues for middle-income countries (about 5 percent of GDP), around 36 cents is recovered from domestic sources of each dollar of lost trade revenue; at half this level of trade taxes, only around 18 cents are recovered.

Further results, which for brevity are not reported here, tend to suggest that the degree of revenue recovery was lower in the second half of the sample period (1987 onwards) than in the first - consistent, for middle-income countries, with the increasing difficulty of dealing with successive declines noted above. Pooling the two income groups to explore regional differences, there are signs that recovery has been more complete in the Americas and, perhaps surprisingly, Africa than it has been in Asia and the Middle East.

\section{Diversity}

The estimation so far has presumed responses to be identical within sample. This may of course disguise considerable diversity of experience across countries, the extent of which can be assessed by estimating a series of country-specific time series. Doing so for each of the low-income countries, ${ }^{23}$ in only six cases out of 38 - Benin, Côte d'Ivoire, The Gambia,

\footnotetext{
${ }^{23}$ The specification is as in Table 2 above, except that to preserve degrees of freedom only openness and income per capita are retained as further regressors. Estimation is by OLS.
} 


\section{Table 6. Further Lags and Non-Linearities, Low- and Middle-Income Countries, $1975-20001 /$}

\begin{tabular}{|c|c|c|c|c|}
\hline & \multicolumn{2}{|c|}{ Low-Income Countries } & \multicolumn{2}{|c|}{ Middle-Income Countries } \\
\hline & FE & GMM 2/ & FE & GMM 2/ \\
\hline \multirow[t]{2}{*}{ Lagged domestic revenue } & $0.655^{* *}$ & $0.575^{* *}$ & $0.638 * *$ & $0.441 * *$ \\
\hline & $(0.032)$ & $(0.045)$ & $(0.026)$ & $(0.08)$ \\
\hline \multirow[t]{2}{*}{ Trade tax to GDP } & 0.087 & -0.044 & 0.037 & 0.182 \\
\hline & $(0.100)$ & $(0.161)$ & $(0.106)$ & $(0.303)$ \\
\hline \multirow[t]{2}{*}{ Lagged trade tax to GDP } & -0.058 & -0.058 & 0.065 & 0.013 \\
\hline & $(0.078)$ & $(0.090)$ & $(0.072)$ & $(0.111)$ \\
\hline \multirow[t]{2}{*}{ Second lag of trade tax to GDP } & 0.021 & -0.006 & 0.070 & 0.016 \\
\hline & $(0.061)$ & $(0.050)$ & $(0.057)$ & $(0.010)$ \\
\hline$(\text { Trade tax to GDP })^{2}$ & $\begin{array}{r}-0.004 \\
(0.003)\end{array}$ & $\begin{array}{r}-0.002 \\
(0.005)\end{array}$ & $\begin{array}{l}-0.012 * * \\
(0.004)\end{array}$ & $\begin{array}{l}-0.024^{* *} \\
(0.010)\end{array}$ \\
\hline \multirow[t]{2}{*}{ Trade tax $\times$ VAT } & 0.085 & 0.349 & -0.008 & 0.055 \\
\hline & $(0.123)$ & $(0.224)$ & $(0.103)$ & $(0.238)$ \\
\hline \multirow[t]{2}{*}{ VAT } & -0.891 & -0.698 & 2.338 & -2.600 \\
\hline & $(0.123)$ & $(4.916)$ & $(2.803)$ & $(7.564)$ \\
\hline \multirow[t]{2}{*}{ Openness } & $0.036^{* *}$ & 0.050 & 0.003 & $0.016^{*}$ \\
\hline & $(0.009)$ & $(0.009)$ & $(0.004)$ & $(0.006)$ \\
\hline \multirow[t]{2}{*}{ Openness $\times$ VAT } & $-0.028 * *$ & $-0.047 * *$ & $0.017 * *$ & 0.016 \\
\hline & $(0.010)$ & $(0.023)$ & $(0.008)$ & $(0.017)$ \\
\hline \multirow[t]{2}{*}{ Log per capita GDP } & 0.163 & $1.887 * *$ & 0.042 & -1.963 \\
\hline & $(0.678)$ & $(0.653)$ & $(0.562)$ & $(1.868)$ \\
\hline \multirow[t]{2}{*}{ Log per capita GDP $\times$ VAT } & 0.340 & 0.395 & -0.529 & 0.060 \\
\hline & $(0.493)$ & $(0.901)$ & $(0.378)$ & $(1.038)$ \\
\hline \multirow[t]{2}{*}{ Log inflation } & -0.062 & -0.084 & 0.072 & 0.171 \\
\hline & $(0.099)$ & $(0.143)$ & $(0.077)$ & $(0.126)$ \\
\hline \multirow[t]{2}{*}{ Aid per capita } & -0.002 & -0.004 & $-0.004 * *$ & -0.001 \\
\hline & $(0.005)$ & $(0.004)$ & $(0.001)$ & $(0.002)$ \\
\hline \multirow[t]{2}{*}{ Share of agriculture } & 0.020 & 0.018 & -0.032 & -0.100 \\
\hline & $(0.020)$ & $(0.024)$ & $(0.025)$ & $(0.088)$ \\
\hline $\mathrm{R}^{2}$ & 0.828 & & 0.875 & \\
\hline $\mathrm{m} 13 /$ & & $-3.21 * *$ & & $-3.28 * *$ \\
\hline $\mathrm{m} 23 /$ & & 0.30 & & 0.44 \\
\hline Sargan 4/ & & 1.0 & & 1.0 \\
\hline Number of countries & 35 & 35 & 50 & 49 \\
\hline Number of observations & 571 & 505 & 925 & 855 \\
\hline
\end{tabular}

Source: Authors' calculations.

1/ Dependent variable is ratio of domestic tax revenue to GDP. Full set of year dummies in all regressions. Standard errors in parentheses; $* *(*)$ indicates significance at $5(10)$ percent.

$2 /$ One step estimates with robust standard errors, except as in footnote 4.

3/ Distributed N(0,1) under the null.

4/ p-value from two-step GMM. 
Malawi, Pakistan, and Zambia - is the implied value of $\theta$ positive ${ }^{24}$ and significantly different from zero at 10 percent or better (the average value for this group being close to unity). There are thus, some low-income countries that appear to have coped well with the revenue losses from trade liberalization, and their experiences warrant further study. But such examples are few.

\section{Conclusions}

Further trade liberalization in many developing countries may be hindered unless they are able to find alternative sources of revenue. There is a body of theoretical results and practical advice setting out strategies for doing this, generally recommending increases in excise taxation and broad-based consumption taxes. This paper, however, has focused on the simple question of fact: Over the last 25 years, have countries actually managed to offset reductions in trade tax revenues by increasing their domestic tax revenues?

For high-income countries, the answer is clearly 'yes.' For middle-income countries, there is also evidence of significant recovery: there are strong signs that this has been in the order of 45-60 cents of additional domestic tax revenue for each dollar of trade tax revenue, with apparently full recovery when separately identifying the episodes in which trade tax revenues fell. For low-income countries, however, recovery has been far from complete. At best, they have on average recovered no more than around 30 cents of each lost dollar. Since many of these countries also face an intense need to enhance revenue to provide sustainable finance for poverty relief and development, and may also face revenue pressures from other sources, ${ }^{25}$ the auspices for the prospect and impact of further trade liberalization are troubling.

Nor do the results here point to any simple solution to these revenue challenges. While there are some signs that the adoption of a VAT has proved helpful in middle- (and high-) income countries, there is no systematic evidence that low-income countries with a VAT have recovered more than those without.

Behind these generalizations, it has also been seen, are quite diverse country experiences. In particular, it has been seen that there are some - a few-low-income countries that have succeeded in reducing trade tax revenues while maintaining, or increasing, the overall tax ratio. Closer examination of these cases may provide guidance for other countries seeking to replace lost trade tax revenues. While the simple presence or absence of a VAT emerges from the econometrics as of little importance to the degree of recovery, for example, it may

\footnotetext{
${ }^{24}$ In one case (Niger) was it significantly negative.

${ }^{25}$ There is some evidence, in particular, that corporate tax revenues in many lower income countries-a more important source of revenue than in developed countries - are under pressure from intensified international tax competition: see Keen and Simone (2004).
} 
be that VATs that meet the orthodox desiderata of a single base, minimal exemptions, and reasonable threshold enable a significantly better performance that those without. Uganda, for instance, has broadly this kind of VAT, and more than offset a reduction in trade tax revenues of nearly 3 percent of GDP over the 1990s by increasing consumption tax revenue by about 4.5 points. Egypt, in contrast, has a VAT characterized by imperfect crediting on capital goods, multiple rates, and imperfect coordination with the excises - and has seen revenue fall over the 1990s by even more than trade taxes alone have fallen. Informal inspection of the data also suggests that those countries which succeeded in recovering lost trade tax revenues did so by increasing not only revenue from domestic consumption taxesthe standard prescription - but also by strengthening the income tax. It may be, for instance, that increased income taxation helps allay political economy difficulties that an increased reliance on consumption taxes, perceived (rightly or not) as regressive might cause.

Finally, it should be stressed that the results here do not imply that trade reforms that have lowered trade tax revenues in developing countries were unwise. Revenue is not the only policy concern, and indeed it is possible that indirect effects operating through higher levels of openness and income consequent upon trade reform have more than offset the direct loss of revenue identified here. From the perspective of fiscal prudence, however, the present results do suggest that the revenue problem to be faced in taking forward trade liberalization, especially in low-income countries, is a real one. 


\section{Data}

Trade tax revenue is defined as import and export duties, taken from Government Finance Statistics (GFS) or IMF country documents, as discussed in the text.

Domestic tax revenue is defined as total tax revenue excluding trade tax revenue, taken from the GFS or IMF country documents, as discussed in the text.

VAT dummy (with the value of 1 if a VAT is in place in any given year, 0 otherwise) is from information in Ebrill and others (2001).

Log per capita GDP is calculated in constant (1995) U.S. dollars, taken from the World Bank's World Development Indicators database.

Openness is calculated as imports plus exports in percent of GDP, taken from the International Financial Statistics (IFS) database.

Log inflation is the annual change in CPI, taken from the IFS database.

Aid per capita is the amount of official development assistance (grants plus concessional loans) in U.S. dollars received per capita, taken from the World Development Indicators database.

Share of agriculture is the share of agriculture in aggregate value added, taken from the World Development Indicators database.

Table 7 summarizes the data, distinguishing between the three income groups. Table 8 shows the country coverage, distinguishing by income group and region. 
Table 7. Summary of Data

\begin{tabular}{|c|c|c|c|c|c|c|}
\hline & & Observations & Mean & Maximum & Minimum & $\begin{array}{l}\text { Standard } \\
\text { Deviation }\end{array}$ \\
\hline $\begin{array}{l}\text { Trade tax revenues } \\
\text { (In percent of GDP) }\end{array}$ & $\begin{array}{l}\text { Low } \\
\text { Medium } \\
\text { High }\end{array}$ & $\begin{array}{r}953 \\
1,321 \\
709\end{array}$ & $\begin{array}{r}4.7 \\
5.0 \\
1\end{array}$ & $\begin{array}{l}33.3 \\
26.8 \\
12.7\end{array}$ & $\begin{array}{l}0.0 \\
0.0 \\
0.0\end{array}$ & $\begin{array}{l}4.7 \\
4.2 \\
2.0\end{array}$ \\
\hline $\begin{array}{l}\text { Domestic tax revenues } \\
\text { (In percent of GDP) }\end{array}$ & $\begin{array}{l}\text { Low } \\
\text { Medium } \\
\text { High }\end{array}$ & $\begin{array}{r}951 \\
1,321 \\
709\end{array}$ & $\begin{array}{r}9.6 \\
14.1 \\
32.0\end{array}$ & $\begin{array}{l}32.1 \\
39.2 \\
55.0\end{array}$ & $\begin{array}{l}0.9 \\
1.2 \\
0.1\end{array}$ & $\begin{array}{r}9.6 \\
6.6 \\
12.0\end{array}$ \\
\hline VAT dummy & $\begin{array}{l}\text { Low } \\
\text { Medium } \\
\text { High }\end{array}$ & $\begin{array}{r}1,066 \\
0.3 \\
728\end{array}$ & $\begin{array}{r}0.2 \\
1456 \\
0.6\end{array}$ & $\begin{array}{l}1 \\
1 \\
1\end{array}$ & $\begin{array}{l}0 \\
0 \\
0\end{array}$ & $\begin{array}{l}0.3 \\
0.5 \\
0.6\end{array}$ \\
\hline $\begin{array}{l}\text { Openness } \\
\text { (In percent of GDP) }\end{array}$ & $\begin{array}{l}\text { Low } \\
\text { Medium } \\
\text { High }\end{array}$ & $\begin{array}{r}923 \\
1,300 \\
663\end{array}$ & $\begin{array}{l}56.1 \\
90.1 \\
75.2\end{array}$ & $\begin{array}{l}279.7 \\
251.7 \\
373.3\end{array}$ & $\begin{array}{r}0 \\
11.5 \\
15.8\end{array}$ & $\begin{array}{l}56.1 \\
44.4 \\
52.8\end{array}$ \\
\hline $\begin{array}{l}\text { GDP per capita } \\
\text { (1995 U.S. dollar) }\end{array}$ & $\begin{array}{l}\text { Low } \\
\text { Medium } \\
\text { High }\end{array}$ & $\begin{array}{r}967 \\
1,368 \\
724\end{array}$ & $\begin{array}{r}413.7 \\
2,491 \\
21,440\end{array}$ & $\begin{array}{r}1,599 \\
10,811 \\
56,732\end{array}$ & $\begin{array}{r}84.7 \\
134 \\
3,023\end{array}$ & $\begin{array}{r}241.1 \\
1,943 \\
9,133.00\end{array}$ \\
\hline $\begin{array}{l}\text { Inflation } \\
\text { (Percent) }\end{array}$ & $\begin{array}{l}\text { Low } \\
\text { Medium } \\
\text { High }\end{array}$ & $\begin{array}{r}787 \\
1,219 \\
675\end{array}$ & $\begin{array}{r}16.1 \\
41.8 \\
6.5\end{array}$ & $\begin{array}{r}200 \\
11,750 \\
84.2\end{array}$ & $\begin{array}{r}-13.1 \\
-11.7 \\
-1.8\end{array}$ & $\begin{array}{r}16.1 \\
427.8 \\
7.5\end{array}$ \\
\hline Aid per capita & $\begin{array}{l}\text { Low } \\
\text { Medium } \\
\text { High }\end{array}$ & $\begin{array}{r}1,061 \\
1,400 \\
728\end{array}$ & $\begin{array}{r}42.6 \\
73.7 \\
1.2\end{array}$ & $\begin{array}{r}638.3 \\
619.6 \\
76.9\end{array}$ & $\begin{array}{r}0.4 \\
-21.6 \\
-4.2\end{array}$ & $\begin{array}{r}50.5 \\
73.7 \\
4.8\end{array}$ \\
\hline $\begin{array}{l}\text { Share of agriculture } \\
\text { (In percent of GDP) }\end{array}$ & $\begin{array}{l}\text { Low } \\
\text { Medium } \\
\text { High }\end{array}$ & $\begin{array}{r}962 \\
1,333 \\
616\end{array}$ & $\begin{array}{r}35.9 \\
15.6 \\
5.2\end{array}$ & $\begin{array}{r}74.3 \\
50.1 \\
25\end{array}$ & $\begin{array}{l}5.3 \\
0.9 \\
0.1\end{array}$ & $\begin{array}{r}12.7 \\
9.1 \\
5.2\end{array}$ \\
\hline
\end{tabular}




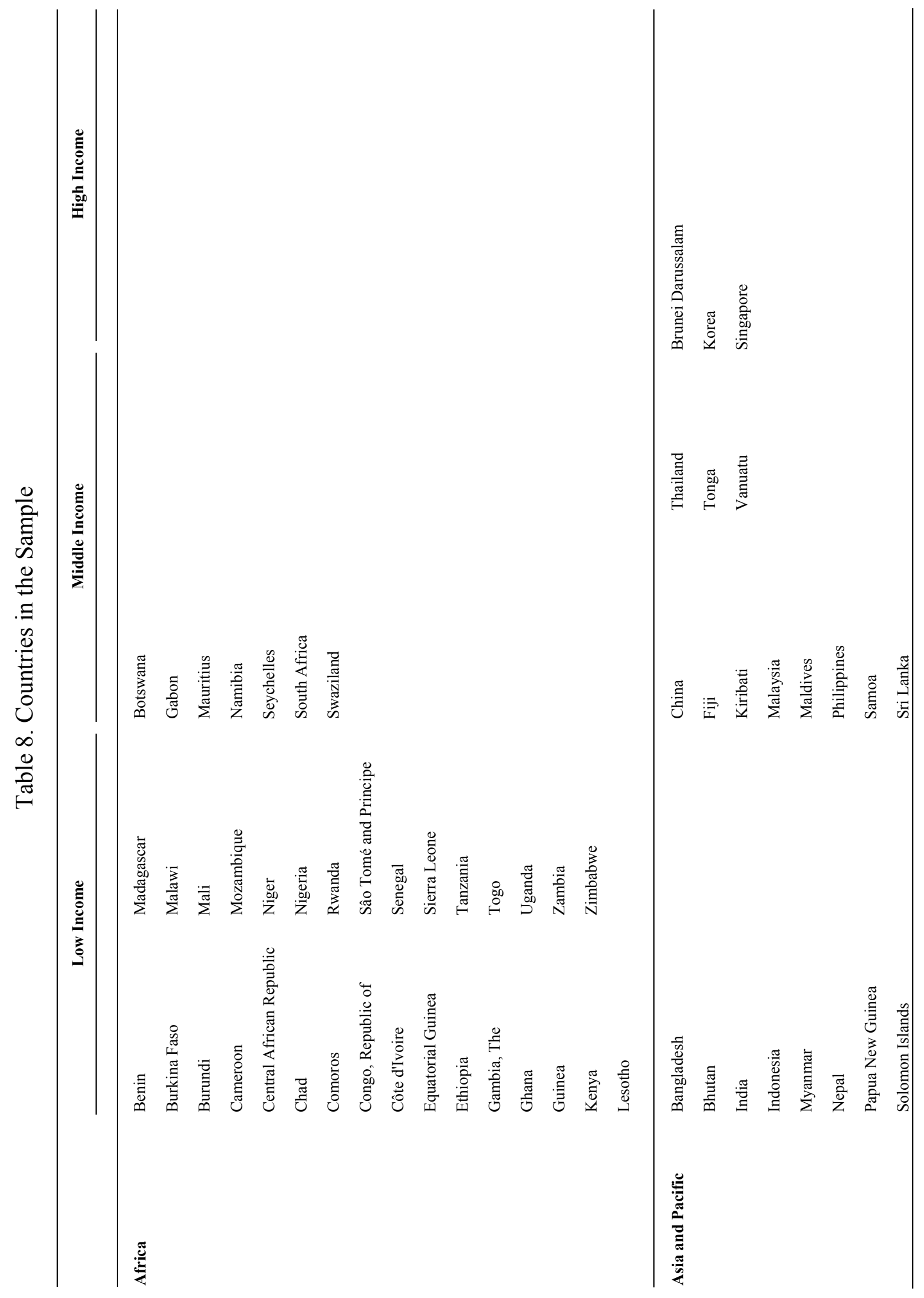




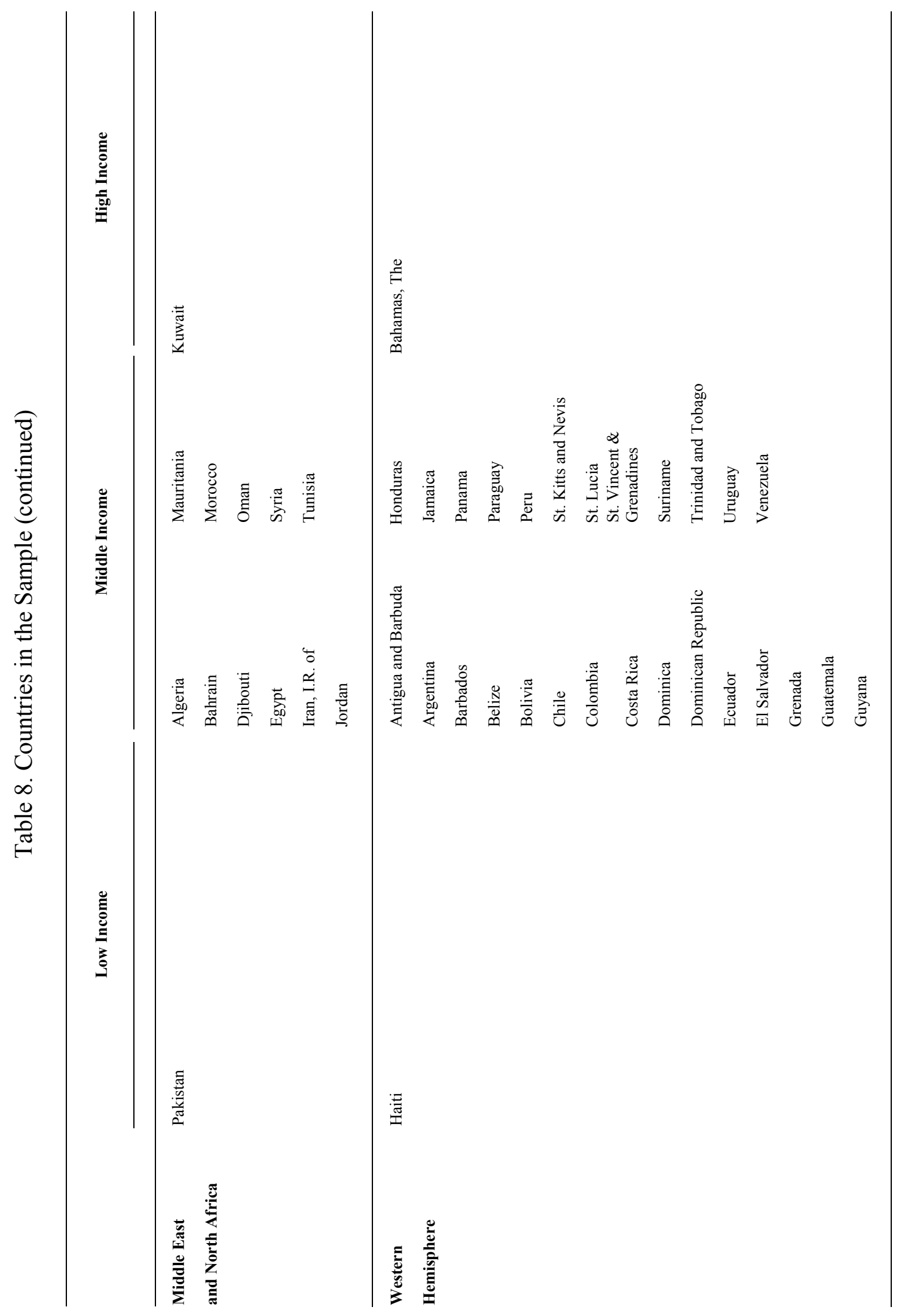




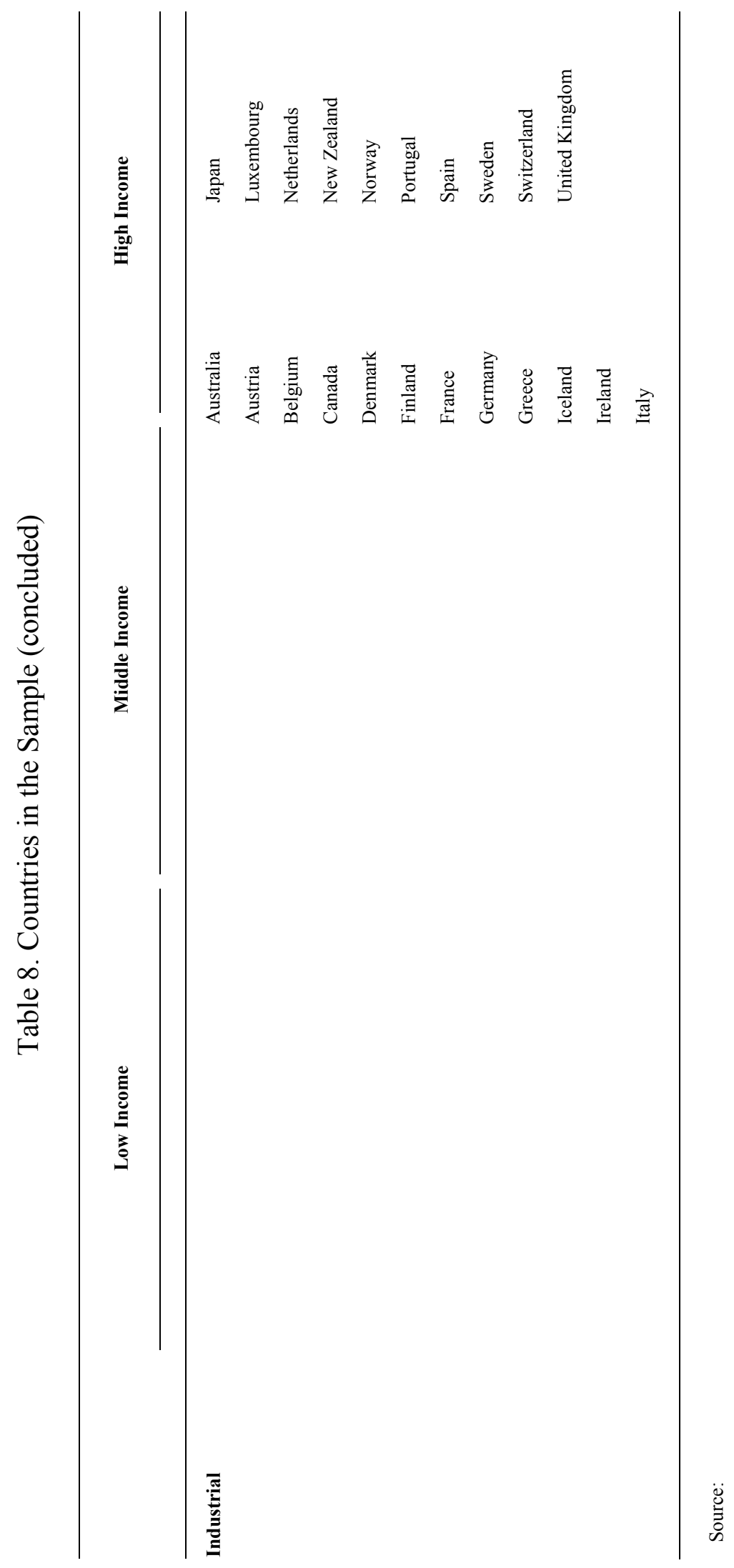




\section{References}

Agbeyegbe, T., J. Stotsky, and A. Woldemariam, 2004, “ Trade Liberalization, Exchange Rate Changes, and Tax Revenue in Sub-Saharan Africa" (unpublished, Washington: International Monetary Fund).

Arrelano, M. and S. Bond, 1991, "Some Tests of Specification for Panel Data: Monte Carlo Evidence and an Application to Employment Equations," Review of Economic Studies, Vol. 58, pp. 277-97.

Ebrill, L., J. Stotsky, and R. Gropp, 1999, Revenue Implications of Trade Liberalization, IMF Occasional Paper No.180 (Washington: International Monetary Fund).

Ebrill, L., M. Keen, J-P. Bodin, and V. Summers, 2001, The Modern VAT (Washington: International Monetary Fund).

Gupta, S., B. Clements, A. Pivovarsky, and E. R. Tiongsin, 2004, "Foreign Aid and Revenue Response: Does the Composition of Aid Matter?" in Sanjeev Gupta, Benedict Clements and Gabriela Inchauste (eds.), Helping Countries Develop: The Role of Fiscal Policy (Washington: International Monetary Fund).

Hatzipanayotou, P., M.S. Michael, and S. M. Miller, 1994, "Win-Win Indirect Tax Reform: A Modest Proposal," Economics Letters, Vol. 44, pp. 147-51.

Keen, M., and B. Lockwood, 2005, "The Value Added Tax-Consequences and Causes," in preparation.

Keen, M., and J. Ligthart, 2001, "Coordinating Tariff Reductions and Domestic Tax Reform," Journal of International Economics, Vol. 56 (2001), pp. 407-425.

, 2005, "Coordinating Tariff Reduction and Domestic Tax Reform Under Imperfect Competition," Review of International Economics, Vol. 13, pp. 385-90.

Keen, M., and A. Simone, 2004, "Tax policy in Developing Countries: Some Lessons from the 1990s, and Some Challenges Ahead," in Sanjeev Gupta, Benedict Clements, and Gabriela Inchauste (eds.): Helping Countries Develop: The Role of the Fiscal Policy (Washington: International Monetary Fund).

Khattry, B., and M. Rao, 2002, "Fiscal Faux Pas? An Analysis of the Revenue Implications of Trade Liberalization," World Development, Vol. 30, pp.1431-44.

Michael, M. S., P. Hatzipanayotou, and S. M. Miller, 1993, "Integrated Reforms of Tariffs and Consumption Taxes," Journal of Public Economics, Vol. 52, 417-28. 
Rodrik, D., 1998, "Why Do More Open Economies have Bigger Governments?" Journal of Political Economy, Vol. 106, pp. 997-1032.

Tanzi, V., 1987, "Quantitative Characteristics of the Tax Systems of Developing Countries," in The Theory of Taxation for Developing Countries, ed. by D. Newbery and N. Stern (Oxford: Oxford University Press), pp. 205-41.

Rajaraman, I., 2004, “Fiscal Restructuring in the Context of Trade Reform," National Institute of Public Finance and Policy, Delhi, Working Paper No. 7.

Wacziarg, R., and K. H. Welch, 2003, "Trade Liberalization and Growth: New Evidence,” NBER Working Paper 10152. 